\title{
Changes of Vital Parameters after Administration of Butorphanol during Tiletamine- Zolazepam-Ketamine-Xylazine Anaesthesia for Joint Surgery in Miniature Pigs
}

\author{
P. RAUŠER, L. LEXMAULOVÁ, R. SRNEC, J. LORENZOVÁ, H. KECOVÁ, M. CRHA, T. FICHTEL, \\ R. NOVOTNÁ, M. DVOŘÁK, A. NEČAS
}

Department of Surgery and Orthopaedics, Small Animal Clinic, University of Veterinary and Pharmaceutical Sciences, Brno, Czech Republic

Received April 30, 2007

Accepted February 14, 2008

\begin{abstract}
Raušer P., L. Lexmaulová, R. Srnec, J. Lorenzová, H. Kecová, M. Crha, T. Fichtel, R. Novotná, M. Dvořák, A. Nečas: Changes of Vital Parameters after Administration of Butorphanol during Tiletamine-Zolazepam-Ketamine-Xylazine Anaesthesia for Joint Surgery in Miniature Pigs. Acta Vet. Brno 2008, 77: 251-256.

The study compares the effects of butorphanol in pigs undergoing joint surgery in tiletamine-zolazepam-ketamine-xylazine (TKX) anaesthesia. A total of 12 pigs were divided into 2 groups by 6 animals - BUT (anaesthetized with TKX combination and butorphanol) and CON (control group - anaesthetized with TKX combination only). All pigs were sedated with a mix of tiletamin-zolazepam-ketamin-xylazin, put into total anaesthesia using propofol, and connected to an anaesthesiology unit $\left(\mathrm{O}_{2}\right.$-Air). For $40 \mathrm{~min}$ we logged the heart rate (HR), respiratory rate $(\mathrm{RR})$, mean arterial pressure (MAP), haemoglobin saturation by oxygen $\left(\mathrm{SpO}_{2}\right)$ and end-tidal $\mathrm{CO}_{2}$ concentration $\left(\mathrm{ETCO}_{2}\right)$ values. Ten minutes after connecting to the devices, the pigs in the BUT group were intravenously administered butorphanol $(0.2 \mathrm{mg} / \mathrm{kg})$ in the total volume of $2 \mathrm{ml}$, or physiological saline in the same volume. The pigs in the BUT group had a lower $(p<0.05) \mathrm{HR}$ in $5^{\text {th }}, 10^{\text {th }}$ and $25^{\text {th }} \mathrm{min}$, and a lower $\mathrm{RR}$ in the $10^{\text {th }}, 15^{\text {th }}$ and $20^{\text {th }}$ min. MAP, ETCO and $\mathrm{SpO}_{2}$ values did not differ substantially. Butorphanol can thus be identified as a suitable analgesic TKX supplement to anaesthesia of miniature pigs with minimum effect on vital functions.
\end{abstract}

Tiletamine-zolazepam, xylazine, ketamine, analgesia, cartilage lesion

Joint surgeries are very painful. High-quality balanced analgesia is thus the main prerequisite for correctly managed anaesthesia (Gaynor and Muir 2002).

Butorphanol is a mixed opioid agonist/antagonist (Pachter and Evens 1985) with quite a good analgesic effect (Pfeffer et al. 1980). It induces weak sedation, with a minimum negative impact on the cardiovascular system. It may cause a mild decrease of the heart frequency and arterial pressure, or respiration depression in animals (Greene et al. 1990; Trim 1983), which, however, is lower compared to morphine (Trim 1983; Hos good 1990). Butorphanol effects become apparent within several min after intravenous administration. It remains in effect for approximately 2 - $4 \mathrm{~h}$ (Hosgood 1990).

The TKX combination (Henrikson et al. 1995) produces good anaesthesia in pigs, characterized by reliable and rapid induction and good cardiovascular function. These characteristics are very useful in laboratory environment, as easy handling to avoid stress is necessary for research. However, TKX did not provide superior analgesia. This is why we recommend potentiating analgesia with concurrent administration of suitable analgesics, e.g. butorphanol.

The effects of butorphanol administered in total anaesthesia combined xylazine-ketamine (Nishimura et al. 1992), tiletamine-zolazepam-xylazine (Ko et al. 1998), azaperoneketamine and detomidine-ketamine (Brodbelt and Taylor 1999), xylazine-ketamine

Address for correspondence:

MVDr. Petr Raušer, Ph.D.

Small Animal Clinic

University of Veterinary and Pharmaceutical Sciences

Palackého 1/3, 61242 Brno

Czech Republic

Phone: +420 541562362

E-mail: rauserp@ vfu.cz

http://www.vfu.cz/acta-vet/actavet.htm 
Heart rate



Fig. 1. Changes of the heart rate after butorphanol administration asterisk shows the differences $(p<0.05)$ between groups

\section{Mean arterial pressure}

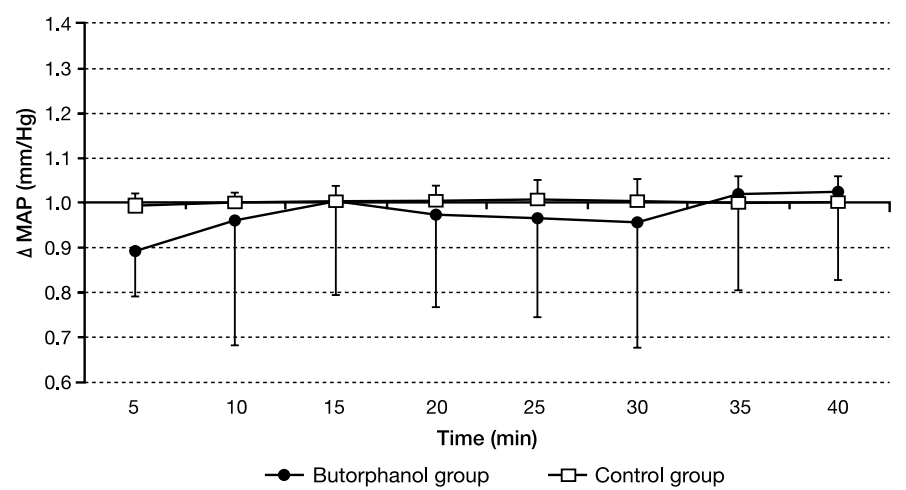

Fig. 2. Changes of the mean arterial pressure after butorphanol administration

\section{Respiratory rate}

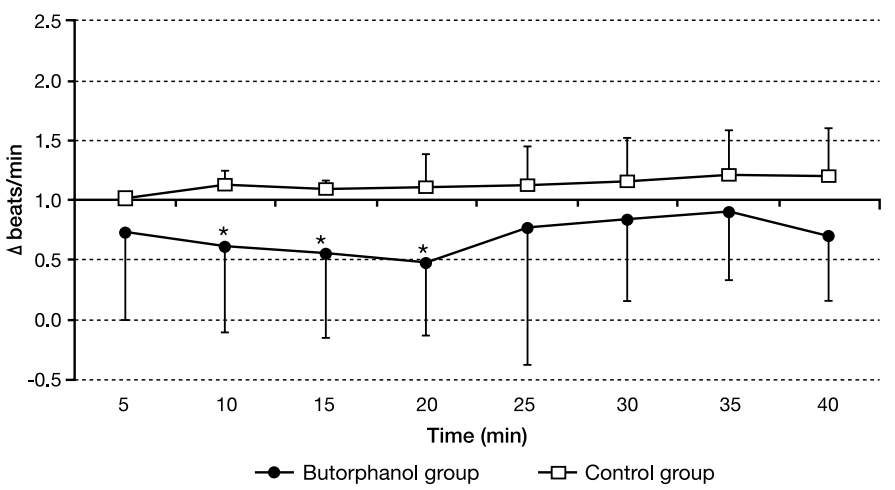

Fig. 3. Changes of the respiratory rate after butorphanol administration asterisk shows the differences $(p<0.05)$ between groups 
(Nishimura et al. 1992) or medetomidine-ketamine were previously described in pigs (Sakaguchi et al. 1996).

The effects of butorphanol combined with a mix of TKX (tiletamine-zolazepamketamine-xylazine) in relation to vital functions in pigs have not been published yet.

Our objective was to detect and compare changes of heart and respiratory rates, mean arterial pressure, haemoglobin saturation by oxygen and end-tidal $\mathrm{CO}_{2}$ concentration after butorphanol administration during TKX anaesthesia for joint surgery in miniature pigs.

\section{Materials and Methods}

Animals

All the anaesthetized animals served as control (in which osteochondral cartilage defects in stifle joints were created) in the experimental study of joint resurfacing using porous scaffolds seeded with mesenchymal stem cells (NPV II Research Project 2B06130). In the study, we used 12 miniature pigs - females aged $2.3 \pm 0.62$ years (mean \pm SD), weighing $17.9 \pm 3.64 \mathrm{~kg}$. All pigs were clinically healthy. They were stabled in the location of experiment for 1 month before the experiment. During the whole study period, the animals were fed, handled and housed according to the principles of welfare. All procedures were carried out with the consent of the Ethics Committee (No. 46613/2003-1020).

Study design

This study was conceived as randomized non-blinded controlled study. A total of 12 miniature pigs were divided into 2 groups by 6 animals - BUT group (anaesthetized with TKX combination and butorphanol) and CON group (control group - anaesthetized with TKX combination only).

Protocol of experiment

Both groups of pigs were intramuscularly administered tiletamine-zolazepam (Zoletil 100, Virbac, France) at the dose of $2 \mathrm{mg} / \mathrm{kg}$, xylazine (Sedazine, Fort Dodge, USA) at the dose of $2 \mathrm{mg} / \mathrm{kg}$ and ketamine (Ketaset, Fort Dodge, USA) at the dose of $2 \mathrm{mg} / \mathrm{kg}$. All substances were administered together in a single syringe. After the start of sedation $10 \mathrm{~min}$ after administration, intravenous catheter with propofol was inserted in the ear vein (Propofol $1 \%$, Fresenius, Austria) at the dose of $1 \mathrm{mg} / \mathrm{kg}$, and an endotracheal tube was inserted in pigs. All pigs were put into the right lateral recumbency and connected to the inhalation circle rebreathing system. They were supplied with a mix of oxygen and air $(1: 1)$ in the amount of $25 \mathrm{ml} / \mathrm{kg} / \mathrm{min}$.

All pigs were connected to a vital functions monitor (Mindray PM-9000Vet, China). Monitoring equipment for this experiment was provided by BIOVENDOR Group, Czech Republic. The logged values included the heart rate (HR), respiratory rate (RR), mean arterial pressure (MAP), haemoglobin saturation by oxygen $\left(\mathrm{SpO}_{2}\right)$ and end-tidal $\mathrm{CO}_{2}$ concentration $\left(\mathrm{ETCO}_{2}\right)$. HR was measured using a 3-lead ECG with electrodes located on the patient's chest. MAP was measured using a disposable blood pressure transducer (Mindray, China) connected to a monitor after calibration. The pressure transducer was connected to the arterial access port (a. auricularis on the contralateral ear to the venous access) using extension tubing filled with heparinized saline (200 IU heparin $\mathrm{ml}^{-1}$, Heparin, Léčiva, Czech Republic). RR and ETCO ${ }_{2}$ were logged using side-stream with a sensor connected to the tip of the endotracheal tube. $\mathrm{SpO}_{2}$ was measured with a sensor connected to the patient's tongue.

$10 \mathrm{~min}$ after connecting the animal to the anaesthetic machine, the BUT group pigs were administered butorphanol (Butomidor, Richter Pharm., Austria) at the dose of $0.2 \mathrm{mg} / \mathrm{kg}$, diluted with saline to the total volume of $2 \mathrm{ml}$. The CON group was intravenously administered $2 \mathrm{ml}$ saline at the same time.

All variables were measured right before the administration of butorphanol/saline $\left(\mathrm{T}_{0}\right)$ and every 5 min over $40 \min \left(\mathrm{T}_{5}-\mathrm{T}_{40}\right)$.

Statistical analysis

The homogeneity of the study groups was established by comparing baseline values $\left(\mathrm{T}_{0}\right)$ for HR, RR, MAP, $\mathrm{SpO}_{2}$ and $\mathrm{ETCO}_{2}$ using Kruskal-Wallis one way ANOVA. $\mathrm{T}_{0}$ value was taken as value 1.0 , values $\mathrm{T}_{5}-\mathrm{T}_{40}$ were logged as a proportional multiple of value $\mathrm{T}_{0}$. The BUT group was compared with CON group by WilcoxonMann-Whitney U-test. The statistical tests were two-sided and used a 0.05 type I error.

\section{Results}

When comparing the body weight and age of pigs, no significant difference was recorded between the BUT and CON groups.

HR values and their changes are shown in Fig. 1. In the BUT group, we recorded significantly higher HR values $(p<0.05)$ in the $5^{\text {th }}, 10^{\text {th }}$ and $25^{\text {th }}$ min.

MAP values and their changes are shown in Fig. 2. Significant differences between BUT and $\mathrm{CON}$ groups were not recorded. 
RR values and their changes are shown in Fig. 3. In the BUT group, we recorded significantly lower RR values $(p<0.05)$ in the $10^{\text {th }}, 15^{\text {th }}$, and $20^{\text {th }}$ min. In 2 animals of the BUT group apnoea occurred, requiring artificial ventilation.

$\mathrm{ETCO}_{2}$ values oscillated depending on the RR. No significant differences in $\mathrm{ETCO}_{2}$ values between BUT and CON groups were recorded.

Neither $\mathrm{SpO}_{2}$ values did show significant deviations; no significant deviations between BUT and CON groups were recorded.

\section{Discussion}

In our study, we used butorphanol at the dose of $0.2 \mathrm{mg} / \mathrm{kg}$ intravenously, which is an average dose recommended by many authors (Brodbelt and Taylor 1999; Nishimura et al. 1992; Sakaguchi et al. 1992, 1996; Ugarte and O'Flaherty 2005). As reported by Greene et al. (1990) or Trim (1983), butorphanol effects on the cardiovascular apparatus are relatively small. In our study, we recorded a mild, yet significant HR decrease $(p<0.05)$ in pigs during concurrent administration of the TKX mix after butorphanol administration. Contrary to Greene et al. (1990) or Trim (1983), however, we did not encounter any blood pressure decrease. Lower HR values were recorded in the $5^{\text {th }}, 10^{\text {th }}$ and $25^{\text {th }}$ min after butorphanol administration, which corresponds with the time of the onset of its effect reported by Hosgood (1990).

Ko et al. (1998) describe the butorphanol effect on anaesthesia in pigs, combined with tiletamine-zolazepam-xylazine, similarly to our study, but without ketamine. They do not mention HR deviation after butorphanol administration (which we recorded), but they mention a decrease of blood pressure that we did not encounter. Ko et al. (1998) also refer to breath depression requiring supplementation of pigs with oxygen, which corresponds to our study, although we used artificial ventilation.

Greene et al. (1990) or Trim (1983) also describe mild breath depression after the administration of butorphanol. In our case, however, breath depression was significant $(p<0.05)$ (in the $10^{\text {th }}, 15^{\text {th }}$, and $\left.20^{\text {th }} \mathrm{min}\right)$ and in 2 pigs it even required artificial ventilation. This does not fully correspond with the aforementioned facts; we can therefore assume that the breath depression was stronger due to the interaction of butorphanol and tiletaminezolazepam-xylazine-ketamine effects.

Bibliographic citations about changes and mutual deviations of $\mathrm{ETCO}_{2}$ are not available, our results cannot thus be compared. Brodbelt and Taylor (1999) mentions mild respiration acidosis with a $\mathrm{SpO}_{2}$ decrease without substantial deviations between animal groups anaesthetized by the combination with butorphanol and without butorphanol. We did not record $\mathrm{SpO}_{2}$ deviations between the groups of miniature pigs we monitored, either; however, we did not monitor the acid base condition of the organism.

When using similar anaesthetic combinations with butorphanol or without it in other animal species, the cited results are similar to our study, but not always entirely identical. Carroll et al. (1997) did not record in goats, similarly to O'Hair et al. (1988) in sheep, any differences between the groups of animals anaesthetized by the combination with butorphanol and without butorphanol. Greene et al. (1990) and Tyner et al. (1989) describe a significant HR and MAP decrease in dogs after butorphanol administration, which is identical to our results. Considering the aforementioned, we may assume that in relation to butorphanol, the pig behaves similarly to dogs, not like small ruminants.

From our results we may perceive butorphanol administration as a suitable supplement to total anaesthesia brought by TKX combination without a substantial effect on the haemodynamic functions of the patient. The respiration function is an exception which may be substantially suppressed.

The TKX combination with butorphanol is suitable namely for laboratory environment and handling to avoid stress, necessary for research projects. In addition, butorphanol 
potentiates superior analgesia and anaesthesia, which is necessary in joint surgeries (Gaynor and Muir 2002), and it is insufficient when only the TKX combination is used (Henrikson et al. 1995).

\section{Změny vitálních parametrů po aplikaci butorfanolu v průběhu TKX anestezie při operacích kloubů u miniaturních prasat}

Studie je zaměřena na srovnání účinků butorfanolu u prasat podstupujících operaci kloubů $\mathrm{v}$ anestezii kombinací tiletaminem-zolazepamem-xylazinem-ketaminem (TKX). Celkem 12 prasat bylo rozděleno do 2 skupin po 6 jedincích - BUT (anestezovaná kombinací TKX a butorfanolem) a CON (kontrolní skupina - anestezovaná samostatnou kombinací TKX). Všechna prasata byla sedována směsí tiletamin-zolazepam-ketamin-xylazin, propofolem uvedena do celkové anestezie a napojena na inhalační anesteziologický př́stroj $\left(\mathrm{O}_{2}\right.$-vzduch). V průběhu 40 min byly zaznamenávány hodnoty srdeční (HR) a dechové (RR) frekvence, středního arteriálního tlaku (MAP), saturace hemoglobinu kyslíkem $\left(\mathrm{SpO}_{2}\right)$ a koncentrace $\mathrm{CO}_{2}$ na konci výdechu $\left(\mathrm{ETCO}_{2}\right)$. Za 10 min po napojení na přístroj byl prasatům skupiny BUT intravenózně podán butorfanol $(0,2 \mathrm{mg} / \mathrm{kg})$ o celkovém objemu $2 \mathrm{ml}$ nebo fyziologický roztok o stejném objemu. Miniaturní prasata skupiny BUT měla v 5., 10. a 25. minutě nižší $(p<0,05)$ hodnoty srdeční frekvence a v 10., 15. a 20. minutě nižší hodnoty dechové frekvence. Hodnoty ETCO a $\mathrm{SpO}_{2}$ se výrazněji nelišily. Butorfanol lze proto označit za vhodný analgetický doplněk TKX anestezie miniaturních prasat s minimálním ovlivněním vitálních funkcí.

\section{Acknowledgement}

This work was supported by the Ministry of Education, Youth and Sports of the Czech Republic (NPV II Research Project 2B06130) and by the Grant Agency AGEL-MH. We thank K. Jaeger and L. Burian for their technical assistance.

\section{References}

BRODBELT DC, TAYLOR PM 1999: Comparison of two combinations of sedatives before anaesthetizing pigs with halothane and nitrous oxide. Vet Rec 145: 283-287

CARROLL GL, HARTSFIELD SM, HAMBLETON R 1997: Anesthetic effects of tiletamine-zolazepam, alone or in combination with butorphanol, in goats. J Am Vet Med Assoc 211: 593-597

GAYNOR JS, MUIR WW 2002: Acute pain management: A case-based approach. In: GAYNOR JS, MUIR WW: Handbook of veterinary pain management. $1^{\text {st }}$ ed. Mosby, St. Louis, pp. 346-380

GREENE SA, HARTSFIELD SM, TYNER CL 1990: Cardiovascular effects of butorphanol in halothane anesthetised dogs. Am J Vet Res 51: 1276-1279

HENRIKSON H, JENSEN-WAERN M, NYMAN G. 1995: Anesthetics for general anesthesia in growing pigs. Acta Vet Scand 36: 401-411

HOSGOOD G 1990: Pharmacologic features of butorphanol in dogs and cats. J Am Vet Med Assoc 1: 135-136

KO JC, NICKLIN CF, MONTGOMERY T, KUO WC 1998: Comparison of anesthetic and cardiorespiratory effects of tiletamine-zolazepam-xylazine and tiletamine-zolazepam-xylazine-butorphanol in ferrets. J Am Anim Hosp Assoc 34: 164-174

NISHIMURA R, SAKAGUCHI M, MOCHIZUKI M, SASAKI N, TAKAHASHI H, TAMURA H, TAKEUCHI A 1992: A balanced anesthesia with a combination of xylazine, ketamine and butorphanol and its antagonism by yohimbine in pigs. J Vet Med Sci 54: 615-620

O'Hair KC, Dodd KT, Phillips YY, Beattie RJ 1988: Cardiopulmonary effects of nalbuphine hydrochloride and butorphanol tartrate in sheep. Lab Anim Sci 38: 58-61

PACHTER IJ, EVENS RP 1985: Butorphanol. Drug Alcohol Depend 14: 325-338

PFEFFER M, SMYTH RD, PITTMAN KA, NARDELLA PA 1980: Pharmacokinetics of subcutaneous and intramuscular butorphanol in dogs. J Pharm Sci 69: 801-803

SAKAGUCHI M, NISHIMURA R, SASAKI N, ISHIGURO T, TAMURA H, TAKEUCHI A 1992: Enhancing effect of butorphanol on medetomidine-induced sedation in pigs. J Vet Med Sci 54: 1183-1185

SAKAGUCHI M, NISHIMURA R, SASAKI N, ISHIGURO T, TAMURA H, TAKEUCHI A 1996: Anesthesia induced in pigs by use of a combination of medetomidine, butorphanol, and ketamine and its reversal by administration of atipamezole. Am J Vet Res 57: 529-534

TRIM CM 1983: Cardiopulmonary effects of butorphanol tartrate in dogs. Am J Vet Res 44: 329-331 
TYNER CL, GREENE SA, HARTSFIELD SM 1989: Cardiovascular effects of butorphanol administration in isoflurane- $\mathrm{O}_{2}$ anesthetized healthy dogs. Am J Vet Res 50: 1340-1342

UGARTE CE, O'FLAHERTY K 2005: The use of a medetomidine, butorphanol and atropine combination to enable blood sampling in young pigs. N Z Vet J 53: 249-252 